\title{
On the selective methylation of benzoyl and furoylthiocarbamates
}

\author{
Ana M. Plutín, ${ }^{a}$ Margarita Suárez, ${ }^{\text {a* }}$ Teresita Machado, ${ }^{a}$ Anislay Álvarez, \\ Alfredo Rodríguez, ${ }^{a}$ Roberto Martínez, bulio Duque, ${ }^{c}$ \\ Roberto Martínez-Álvarez, ${ }^{\mathrm{d}}$ and Nazario Martín ${ }^{\mathrm{d}}$ * \\ ${ }^{a}$ Laboratorio de Síntesis Orgánica, Facultad de Química, Universidad de La Habana, 10400, La \\ Habana, Cuba \\ ${ }^{b}$ Instituto de Química, Universidad Autónoma de México. Ciudad Universitaria, México D.F. \\ México \\ ${ }^{c}$ Departamento de Análisis Estructural, Instituto de Ciencias y Tecnología de los Materiales. \\ Universidad de La Habana 10400. La Habana, Cuba \\ ${ }^{d}$ Departamento de Química Orgánica. Facultad de Ciencias Químicas. Universidad \\ Complutense de Madrid. 28040-Madrid. Spain \\ E-mail: msuarez@fq.uh.cu, nazmar@quim.ucm.es
}

\begin{abstract}
The methylation reaction of alkyl $\mathrm{N}$-acylthiocarbamates in DMF with dimethyl sulfate in the presence of potassium carbonate takes place with high selectivity affording the $S$-methylated derivative as the principal reaction product. No isomeric reaction products derived from the $N$ - or the $O$-methylation were isolable. The new carbonimidothioates 3a-g synthesised were fully characterized by spectroscopic methods. The experimental findings are supported by X-ray and theoretical studies at the B3LYP/6-311G(d.p) level.
\end{abstract}

Keywords: Methylation, polydentate system, structural study, X ray diffraction, thiocarbamic ester

\section{Introduction}

Polydentate systems have received considerable attention due to their use as chelating ligands of multivalent metal ions and by the attempt to justify and to predict the major reaction products from compounds with several reaction sites. So, effort has been made to study the alkylation reaction of systems exhibiting multiple reaction sites, in which the different alternative reaction routes present very small free energy differences. ${ }^{1}$

Thiocarbamate derivatives are well-known systems that have received a lot of attention due to their interesting technological ${ }^{2}$ and biological applications. ${ }^{3}$ Most notably, thiocarbamate 
derivatives are used as elastase inhibitors, ${ }^{4}$ and they can exhibit antineoplastic ${ }^{5}$ and antiinflammatory $^{6}$ effects. In addition, recent paper have reported the studies of new acylthiocarbamates as potent non-nucleoside HIV-1 reverse transcriptase inhibitors. ${ }^{7}$

$O$-Alkyl- $N$-acylthiocarbamate derivatives have been proposed as intermediates for regio- and chemoselective deoxygenation of primary and secondary aliphatic alcohols. ${ }^{8}$ In addition, $O$ alkyl- $N$-aroylthiocarbamates are useful as sequestering substances of heavy metal ions in aqueous solutions. ${ }^{9}$ Furthermore, it has also been reported that $N$-benzoylthiocarbamic- $O$ alkylesters are weak monoprotic acids which behave as fairly stable and versatile bidentate $(O, S)$-chelating ligands towards multivalent metal ions like $\mathrm{Ni}(\mathrm{II}), \mathrm{Cu}(\mathrm{II})$ and $\mathrm{Pb}(\mathrm{II}){ }^{10} \mathrm{These}$ derivatives are also employed in liquid-liquid extractions of silver(I) ions. ${ }^{11}$ Moreover, the use of bis $(O$-alkyl- $N$-benzoylthiocarbamate) in the formation of nickel(II) complexes has also been studied. $^{12}$

On the other hand, the synthesis, characterization and structure of some thiocarbamate derivatives has been extensively studied. ${ }^{13-18}$ The crystal structures of some derivatives such as those of $\mathrm{O}$-isopropyl- $\mathrm{N}$-(2-furoyl)thiocarbamate, ${ }^{13} \mathrm{O}$-benzyl- $\mathrm{N}$-(2-furoyl)thiocarbamate, ${ }^{14} \mathrm{O}, \mathrm{O}$ diethyl- $N, N$-(p-phenylenedicarbonyl)-bis(thiocarbamate) ${ }^{15}$ and $O, O$-dimethyl- $N, N-(m-$ phenylenedicarbonyl)-bis(thiocarbamate), have also been reported in the literature. ${ }^{16} \mathrm{~N}$ acylthiocarbamates have also been employed as starting compounds to obtain a variety of different heterocyclic compounds such as aminothiazoles, thietanes, aminotetrazoles, thiadiazoles, or thiadiazolines. ${ }^{19}$

As part of our studies on the behaviour of polydentate molecules, in previous work we have reported the highly selective $S$-alkylation of benzoyl and furoylthioureas and these results were supported by means of NMR experiments, X-ray studies and semiempirical theoretical calculations. $^{20}$ In a previous work, we have reported the synthesis of new alkyl $N$ acylthiocarbamates and the crystalline structure of isopropyl $N$-furoylthiocarbamate and determined that the molecule exists in the $E, Z^{\prime}$ conformation which is stabilised because of the presence of an intramolecular hydrogen bonding between the furan oxygen and the N-H of the amide group. $^{21}$ (See Figure 1).

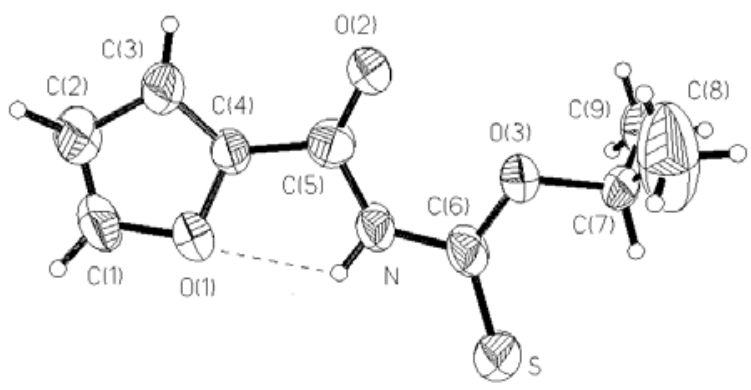

Figure 1. Crystal structure of isopropyl $N$-(2-furoyl)thiocarbamate showing the E, $Z^{\prime}$ conformation. $^{20}$ 
In continuation of our interest in the chemistry of multiple site reactive systems, in this paper we describe the X-ray crystallographic study of butyl $N$-benzoylthiocarbamate and the methylation reaction of various alkyl $\mathrm{N}$-furoyl- and alkyl $\mathrm{N}$-benzoylthiocarbamates in order to account for the selectivity observed in the reactivity of these multiple site reactive systems. The methylation was carried out by treatment of a solution of the corresponding alkyl $\mathrm{N}$ acylthiocarbamates in DMF with dimethyl sulfate in the presence of potassium carbonate. In addition, justification of the obtained experimental results has been carried out by X-ray studies.

\section{Results and Discussion}

Alkyl $\mathrm{N}$-acylthiocarbamates 1 afford anions 2 in the presence of weak bases and, consequently, the alkylation reaction of compounds 1 could take place on any of their three heteroatoms leading to a mixture of three different isomeric products 3, 4 or 5 resulting from the $S$-, $N$ - and $O$-methylation, respectively (Scheme 1).

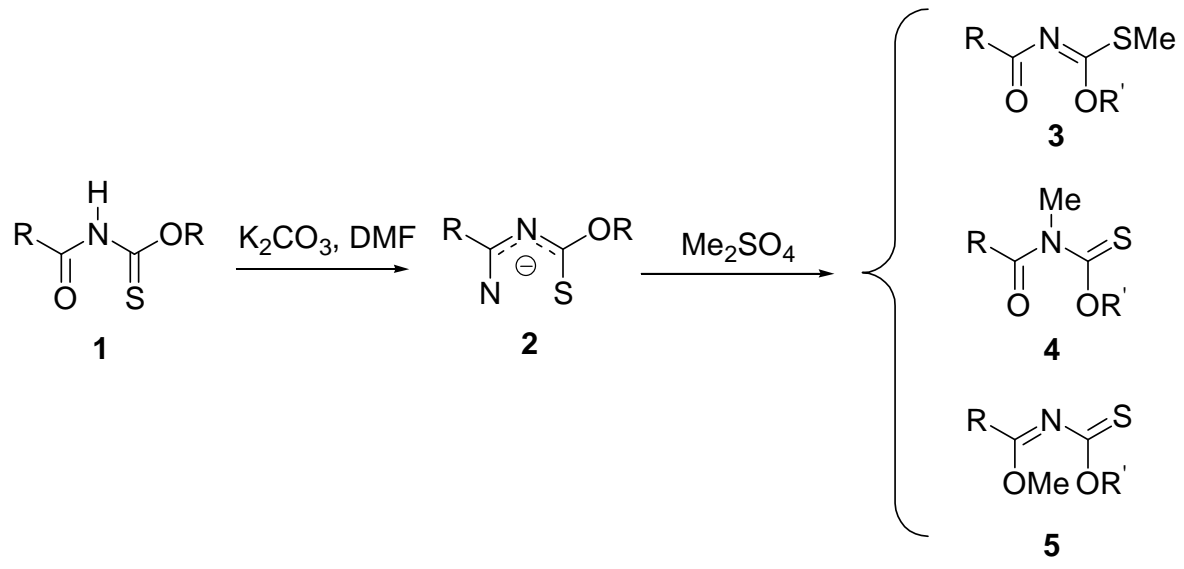

Scheme 1. Alkylation of thiocarbamates 1.

The thiocarbamates 1 were prepared according to the procedure described previously ${ }^{21}$ by using acid chlorides and ammonium thiocyanate in acetone. The intermediate isothiocyanate reacts in situ with the corresponding alcohol affording 1.

The addition of potassium carbonate to a solution of different compounds $\mathbf{1}$ in dimethylformamide resulted in a fast decoloration of the solution, which could indicate the formation of the respective anionic species 2. Further addition of the alkylating reagent, $\mathrm{Me}_{2} \mathrm{SO}_{4}$, led to the $S$-methylated compounds 3 as the only isolable reaction product. As expected, the behavior of a variety of differently substituted compounds $\mathbf{1}$ in the methylation reactions is quite similar and the $S$-methyl derivatives 3a-g are thus obtained in good yields (see Table 1). 
Table 1. Synthesis of compounds 3

\begin{tabular}{ccccc}
\hline Entry & 3 & $\mathrm{R}$ & $\mathrm{R}^{\prime}$ & Yield (\%) $^{\mathrm{a}}$ \\
\hline 1 & 3a & 2 -Furyl & $\mathrm{Me}$ & 82 \\
2 & 3b & $2-\mathrm{Furyl}$ & $\mathrm{Et}$ & 81 \\
3 & 3c & $2-\mathrm{Furyl}$ & $i-\mathrm{Pr}$ & 79 \\
4 & $\mathbf{3 d}$ & $\mathrm{Ph}$ & $i-\mathrm{Pr}$ & 81 \\
5 & $\mathbf{3 e}$ & $\mathrm{Ph}$ & $\mathrm{Bu}$ & 80 \\
6 & $\mathbf{3 f}$ & $p-\mathrm{NO}_{2} \mathrm{C}_{6} \mathrm{H}_{4}$ & $i-\mathrm{Pr}$ & 77 \\
7 & $\mathbf{3 g}$ & $p-\mathrm{FC}_{6} \mathrm{H}_{4}$ & $i-\mathrm{Pr}$ & 76 \\
\hline
\end{tabular}

${ }^{a}$ Yield based on compounds $\mathbf{1}$ after recrystallization of $\mathbf{3}$ from acetone.

The formation of the $\mathrm{N}$ - and $\mathrm{O}$-methylated derivatives $\mathbf{4}$ and $\mathbf{5}$ were only detected by HPLC. Figure 2 shows the analytical HPLC chromatogram of the reaction mixture for the synthesis of 3e, chosen as a reaction model. At $13.10 \mathrm{~min}$. (87\% yield) the signal corresponding to the $S$ methylated 3e is observed. At 9.13 and $11.42 \mathrm{~min}$. two signals are found that could be reasonably assigned to the $N$ - and $O$-methylated products which are found in minor amounts (6-7\%).

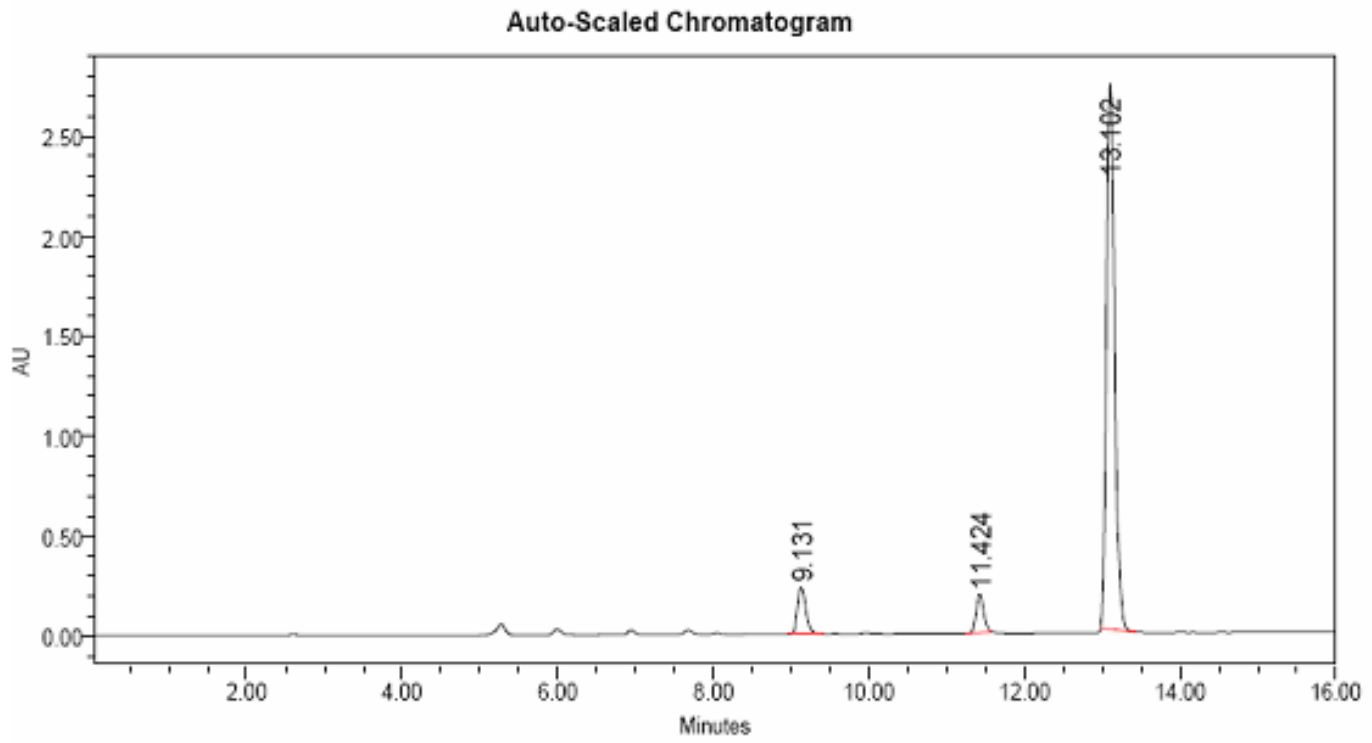

Figure 2. Analytical HPLC of the reaction mixture to obtain $3 \mathbf{e}$.

Structures of the novel compounds 3 were established by their ${ }^{1} \mathrm{H}$ and ${ }^{13} \mathrm{C}$ NMR spectroscopic data. Thus, the signal at $\sim 2.3 \mathrm{ppm}$ in the ${ }^{1} \mathrm{H}-\mathrm{NMR}$ spectra of compounds 3 was assigned to the $-\mathrm{SCH}_{3}$ group and ${ }^{13} \mathrm{C}-\mathrm{NMR}$ spectra of $\mathbf{3}$ showed two signals at $\sim 173.8$ and $\sim 163.3$ ppm corresponding to the $\mathrm{C}=\mathrm{N}$ and $\mathrm{C}=\mathrm{O}$ groups, respectively, and no signal at $\sim 188 \mathrm{ppm}(\mathrm{C}=\mathrm{S}$ 
group) was detected. In addition, the IR spectra of compounds 3 were also in agreement with the proposed structures and no $\mathrm{C}=\mathrm{S}$ band was observed.

In order to explain the high predominance of $S$-alkylation, we analysed the structure of the alkyl $\mathrm{N}$-acylthiocarbamates 1 . It has been established that $\mathrm{N}$-acyl-O-alkylthiocarbamates exist in four possible conformations ${ }^{9}$ as shown in Figure 3.<smiles>[R]OC(=S)NC([R])=O</smiles>

$E, E^{\prime}$<smiles>[R]OC(=S)NC([R])=O</smiles>

$E, Z^{\prime}$<smiles>[R]OC(=S)NC([R])=O</smiles>

$Z, Z^{\prime}$<smiles>[R]OC(=S)NC([R])=O</smiles>

$Z, E^{\prime}$

Figure 3. Conformations of alkyl $N$-acylthiocarbamates.

In this work we have determined the X-ray molecular structure of butyl $\mathrm{N}$ benzoylthiocarbamate 1 and calculated its preferential conformation by B3LYP/6-311G(d.p) (See Figure 4).

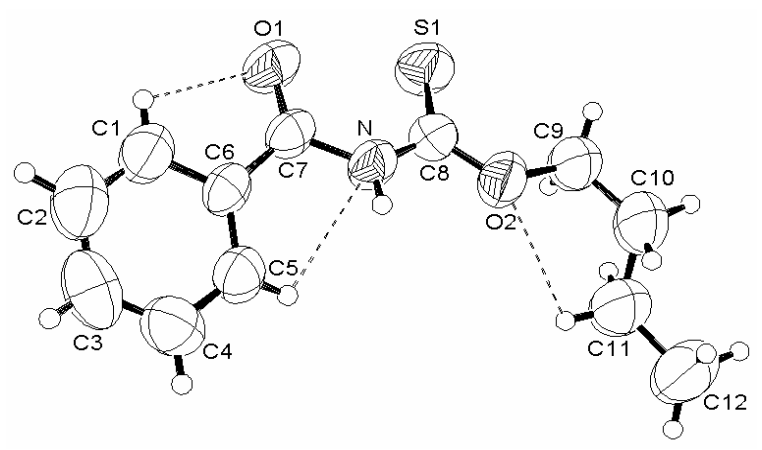

A

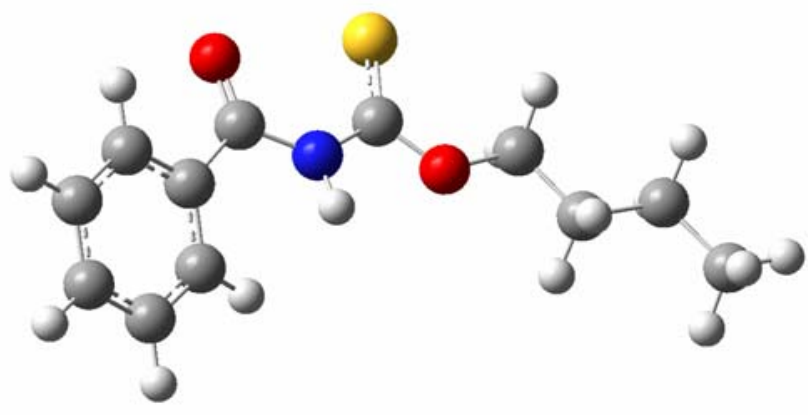

B

Figure 4. (A) Molecular structure of butyl $N$-benzoylthiocarbamate. Ortep diagram with atoms numbering scheme and displacement ellipsoids at $50 \%$ probability level. Intramolecular hydrogen bonds are also indicated. (B) Most stable conformation calculated at the B3LYP/6$311 \mathrm{G}(\mathrm{d} . \mathrm{p})$ level.

Table 2 shows geometrical data calculated for butyl $N$-benzoylthiocarbamate [B3LYP/6$311 \mathrm{G}(\mathrm{d} . \mathrm{p})]$ as well as those determined by $\mathrm{X}$-ray.

$\mathrm{X}$-ray analysis shows that moiety $\mathrm{S} 1=\mathrm{C} 8-\mathrm{N}-\mathrm{C} 7=\mathrm{O}$ is in a nearly planar conformation with torsion angle $\mathrm{S} 1-\mathrm{C} 8-\mathrm{N}-\mathrm{C} 7=-14.5(4)^{\circ}$ and $\mathrm{O} 1-\mathrm{C} 7-\mathrm{N}-\mathrm{C} 8=-0.5(4)^{\circ}$. These values indicate that both carbonyl and thiocarbonyl groups are on the same side of the molecule showing a $Z, Z$ ' conformation, which is in agreement with previously reported results for these types of compounds. ${ }^{15,16,22}$ This conformation is particularly stabilized by three intramolecular hydrogen bond, $\mathrm{N}$ atom and $\mathrm{H} 5$ from the phenyl ring $[\mathrm{N} \cdots \mathrm{C}$ : 2.864(5) $\AA$ ] , the oxygen from the carbonyl 
group and the $\mathrm{H} 1$ from the phenyl ring $[\mathrm{C} 1 \cdots \mathrm{O} 1: 2.769(6) \AA]$ and $\mathrm{H} 11$ (from the methylene group) and the $\mathrm{O} 2$ atom $[\mathrm{C} 11 \cdots \mathrm{O} 2: 2.987(7) \AA]$ (see Table 3). The thioamide group O1-C7-N$\mathrm{C} 8-\mathrm{S}$ is deviated of the planarity with respect to the plane formed by the benzene rings $\mathrm{C} 1-\mathrm{C} 2-$ C3-C4-C5-C6, showing angle of $16.8(2)^{\circ}$. The $Z, Z^{\prime}$ conformation between the $\mathrm{C} 7=\mathrm{O} 1$ and $\mathrm{C} 8=\mathrm{S}$ groups (two donors sites rich in electron density) of the thiourea fragment, can also be explained by the existence of the intermolecular $\mathrm{N}-\mathrm{H}^{\cdots \cdots} \mathrm{O}$ hydrogen bond between the $\mathrm{H}$ atom of the thioamide and the carbonyl $\mathrm{O}$ atom of the related molecule in the crystal structure extending along the [100] direction. Figure 5 shows the crystal packing diagram. The non-bonding $\mathrm{NH}^{\cdots} \cdots(\mathrm{O} 1)$ distance is 2.881(4) $\AA$, similar to the reported values found for other related derivatives. ${ }^{23}$ The existence of the intramolecular and intermolecular hydrogen bonds, may determine the Z,Z'-conformation (O1-C7-N-C8-S1).

It is noteworthy that C7-N and C8-N [1.380(4) $\AA$ and 1.354(5) $\AA$, respectively] are shorter than a normal C-N bond length (1.468 $\AA$ ), which indicates that these bonds have a pronounced double bond character. Therefore, it is possible to assume an electronic delocalization in that part of the molecule. In addition, $\mathrm{C} 8-\mathrm{O} 2$ bond distance $[1.321(4) \AA]$ indicates a partial double bond and a $\pi$-type conjugation in the whole system.

Table 2. Conformational features of butyl $N$-benzoylthiocarbamate and its anion (the numbering scheme is shows in Figure 4). Bond distances are given in $\AA$ and bond angles and torsion angles in degrees (standard deviations in parenthesis)

\begin{tabular}{cccc}
\hline Bond distance & X-ray & $\begin{array}{c}\text { Molecule [ B3LYP/6- } \\
\text { 311G(d.p)] }\end{array}$ & $\begin{array}{c}\text { Anion [ B3LYP/6- } \\
311 \mathrm{G}(\mathrm{d} . \mathrm{p})]\end{array}$ \\
\hline C1-C2 & $1.339(8)$ & 1.39 & 1.40 \\
C2-C3 & $1.349(9)$ & 1.39 & 1.40 \\
C3-C4 & $1.362(9)$ & 1.39 & 1.40 \\
C4-C5 & $1.365(6)$ & 1.39 & 1.40 \\
C5-C6 & $1.360(5)$ & 1.40 & 1.40 \\
C6-C1 & $1.381(5)$ & 1.40 & 1.40 \\
C6-C7 & $1.473(5)$ & 1.50 & 1.52 \\
C9-C10 & $1.494(7)$ & 1.52 & 1.53 \\
C11-C10 & $1.519(8)$ & 1.53 & 1.53 \\
C11-C12 & $1.502(9)$ & 1.53 & 1.53 \\
S1-C8 & $1.626(4)$ & 1.64 & 1.70 \\
O2-C8 & $1.321(4)$ & 1.35 & 1.38 \\
C8-N & $1.354(5)$ & 1.38 & 1.32 \\
C7-N & $1.380(4)$ & 1.40 & 1.35 \\
O1-C7 & $1.203(4)$ & 1.21 & 1.24 \\
Valence angles & & & 120.1 \\
C1-C2-C3 & $120.2(4)$ & 120.1 & 119.5 \\
C2-C3-C4 & $120.6(4)$ & 119.9 & \\
\hline
\end{tabular}


Table 2. Continued

\begin{tabular}{|c|c|c|c|}
\hline Bond distance & X-ray & $\begin{array}{c}\text { Molecule [ B3LYP/6- } \\
\text { 311G(d.p)] }\end{array}$ & $\begin{array}{c}\text { Anion [B3LYP/6- } \\
\text { 311G(d.p)] }\end{array}$ \\
\hline $\mathrm{C} 3-\mathrm{C} 4-\mathrm{C} 5$ & $119.4(4)$ & 120.1 & 120.2 \\
\hline $\mathrm{C} 4-\mathrm{C} 5-\mathrm{C} 6$ & $120.4(3)$ & 120.3 & 120.6 \\
\hline $\mathrm{C} 1-\mathrm{C} 6-\mathrm{C} 7$ & $117.4(3)$ & 116.9 & 118.9 \\
\hline C5-C6-C7 & $124.2(2)$ & 123.9 & 122.3 \\
\hline C6-C7-O1 & $122.2(2)$ & 122.4 & 118.4 \\
\hline C6-C7-N & $116.0(2)$ & 113.7 & 113.5 \\
\hline O1-C7-N & $121.8(3)$ & 123.9 & 128.0 \\
\hline C7-N-C8 & $128.4(2)$ & 129.8 & 126.8 \\
\hline N-C8-S1 & $127.5(2)$ & 128.1 & 129.8 \\
\hline $\mathrm{S} 1-\mathrm{C} 8-\mathrm{O} 2$ & $125.5(2)$ & 125.9 & 120.5 \\
\hline $\mathrm{C} 8-\mathrm{O} 2-\mathrm{C} 9$ & $118.8(2)$ & 119.7 & 120.3 \\
\hline $\mathrm{O} 2-\mathrm{C} 9-\mathrm{C} 10$ & $106.3(3)$ & 107.2 & 107.1 \\
\hline \multicolumn{4}{|l|}{ Torsion angles } \\
\hline $\mathrm{C} 1-\mathrm{C} 2-\mathrm{C} 3-\mathrm{C} 4$ & $-0.2(7)$ & -0.2 & -0.1 \\
\hline $\mathrm{C} 2-\mathrm{C} 3-\mathrm{C} 4-\mathrm{C} 5$ & $0.5(6)$ & 0.7 & 0.0 \\
\hline C3-C4-C5-C6 & $-1.0(5)$ & -0.2 & 0.1 \\
\hline C4-C5-C6-C1 & $1.2(4)$ & -0.9 & -0.1 \\
\hline C5-C6-C7-O1 & $164.5(3)$ & 157.0 & 176.7 \\
\hline C1-C6-C7-O1 & $-13.1(4)$ & -20.9 & 4.1 \\
\hline C6-C7-N-C8 & $165.7(3)$ & 175.6 & 153.5 \\
\hline $\mathrm{O} 1-\mathrm{C} 7-\mathrm{N}-\mathrm{C} 8$ & $-14.5(4)$ & -5.6 & -31.3 \\
\hline C7-N-C8-S1 & $-7.5(4)$ & -9.4 & -31.3 \\
\hline $\mathrm{C} 7-\mathrm{N}-\mathrm{C} 8-\mathrm{O} 2$ & $173.7(3)$ & 171.6 & 153.8 \\
\hline $\mathrm{S} 1-\mathrm{C} 8-\mathrm{O} 2-\mathrm{C} 9$ & $-0.5(4)$ & -0.5 & -0.5 \\
\hline $\mathrm{N}-\mathrm{C} 8-\mathrm{O} 2-\mathrm{C} 9$ & $178.3(3)$ & 178.5 & 175.0 \\
\hline $\mathrm{N}-\mathrm{C} 7-\mathrm{C} 6-\mathrm{C} 5$ & $-15.7(4)$ & -24.2 & -0.9 \\
\hline $\mathrm{N}-\mathrm{C} 7-\mathrm{C} 6-\mathrm{C} 1$ & $166.7(2)$ & 158.0 & 179.8 \\
\hline
\end{tabular}


Table 3. Intra- and intermolecular hydrogen bonds for butyl $N$-benzoylthiocarbamate. Bond distances are given in $\AA$ and bond angles in degrees (standard deviations in parenthesis)

\begin{tabular}{cccc}
\hline $\mathrm{D}-\mathrm{H}$ & $\mathrm{D} \cdots \mathrm{A}$ & $\mathrm{H}^{\cdots \cdots} \mathrm{A}$ & $\mathrm{D}-\mathrm{H}^{\cdots \cdots} \mathrm{A}$ \\
\hline $\mathrm{C}(1)-\mathrm{H}(1): 0.844(3)$ & $\mathrm{C}(1) \cdots \mathrm{O}(1):$ & $\mathrm{H}(1) \cdots \mathrm{O}(1):$ & $\mathrm{C}(1)-\mathrm{H}(1) \cdots \mathrm{O}(1):$ \\
& $2.769(6)$ & $2.435(4)$ & $104.47(2)$ \\
$\mathrm{C}(5)-\mathrm{H}(5): 0.838(3)$ & $\mathrm{C}(5)^{\cdots} \mathrm{N}: 2.864(5)$ & $\mathrm{H}(5) \cdots \mathrm{N}: 2.568(3)$ & $\mathrm{C}(5)-\mathrm{H}(5) \cdots \mathrm{N}: 102.16(2)$ \\
$\mathrm{C}(11)-\mathrm{H}(11 \mathrm{~b}):$ & $\mathrm{C}(11) \cdots \mathrm{O}(2):$ & $\mathrm{H}(11 \mathrm{~b}) \cdots \mathrm{O}(2):$ & $\mathrm{C}(11)-\mathrm{H}(11 \mathrm{~b}) \cdots \mathrm{O}(2):$ \\
$0.970(5)$ & $2.987(7)$ & $2.602(6)$ & $103.86(5)$ \\
$\mathrm{N}-\mathrm{H}: 0.786(2)^{\mathrm{a}}$ & $\mathrm{N}^{\cdots \cdots} \mathrm{O}(1): 2.881(4)^{\mathrm{a}}$ & $\mathrm{H}^{\cdots} \mathrm{O}(1): 2.152(2)^{\mathrm{a}}$ & $\mathrm{N}-\mathrm{H}^{\cdots} \cdots \mathrm{O}(1): 154.43(9)^{\mathrm{a}}$ \\
\hline
\end{tabular}

${ }^{\mathrm{a}}$ Intermolecular hydrogen bonds.

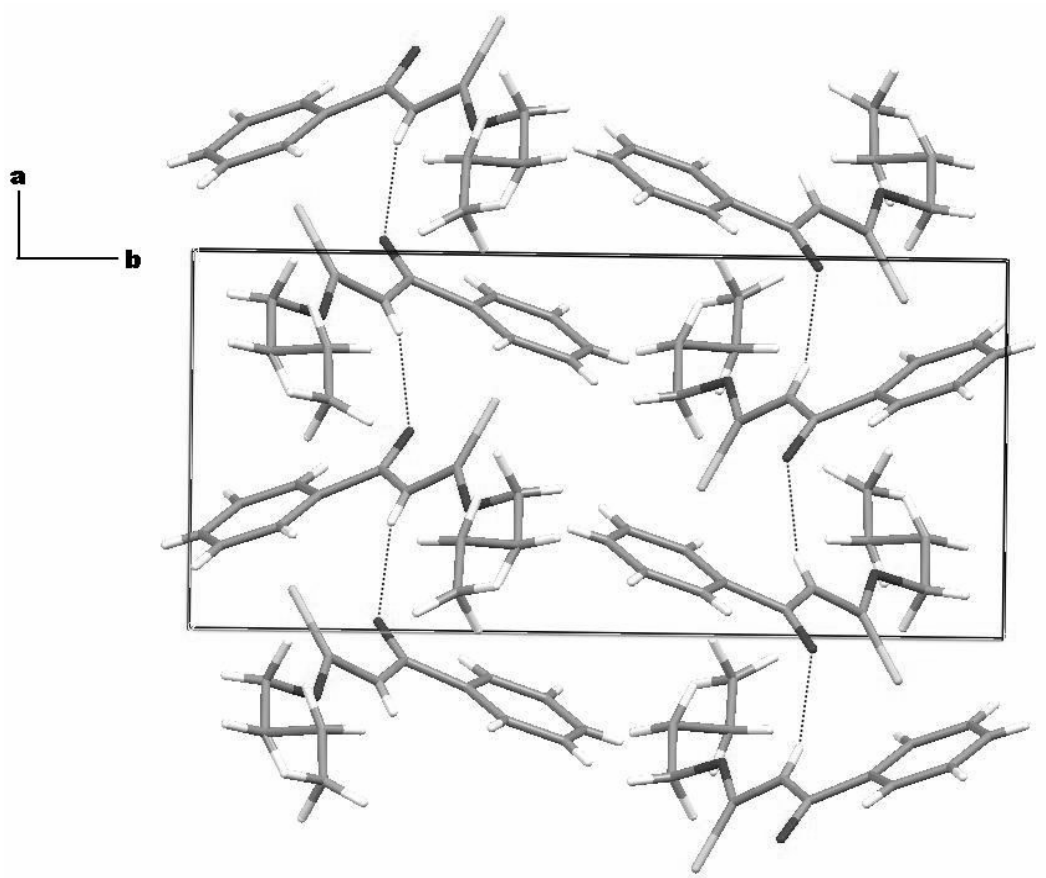

Figure 5. Packing diagram of butyl $N$-benzoylthiocarbamate in the unit cell, showing the hydrogen bond scheme. X-ray crystal structures for the studied compound along the (100) axe.

The geometrical features predicted by B3LYP/6-311G(d.p) calculations and determined by $\mathrm{X}$-ray diffraction listed in Table 2 showed a satisfactory correspondence of the theoretical values with the experimental values and in spite of some differences found in the torsion angles, the results confirmed that the ab initio method report a reliable geometry for the proposed system. These data indicate that the most stable conformation for the calculated molecule is the $Z, Z^{\prime}$. This means that the geometry in gas phase is quite similar to those in solid state. Considering that B3LYP/6-311G(d.p) method reproduces the geometry of these systems, we have determined the 
preferential conformation of the butyl $N$-benzoylthiocarbamate anion by the B3LYP/6$311+\mathrm{G}($ d.p) method.

Figure 6 shows the preferential conformation of the butyl $N$-benzoylthiocarbamate anion. It becomes evident that the predicted lower energy conformation is in agreement with that observed by X-ray diffraction, being either for the neutral acylthiocarbamate or for its anion the conformation with $Z, Z^{\prime}$ geometry.

It should be noted that this geometry provides a greater access to the region of the sulphur atom compared to the $\mathrm{O}$ and $\mathrm{N} 1$ atoms, and this brings about a qualitative explanation for the higher percentage of the $S$-alkylated product in comparison to $\mathrm{N}$ - and $\mathrm{O}$-alkylation.

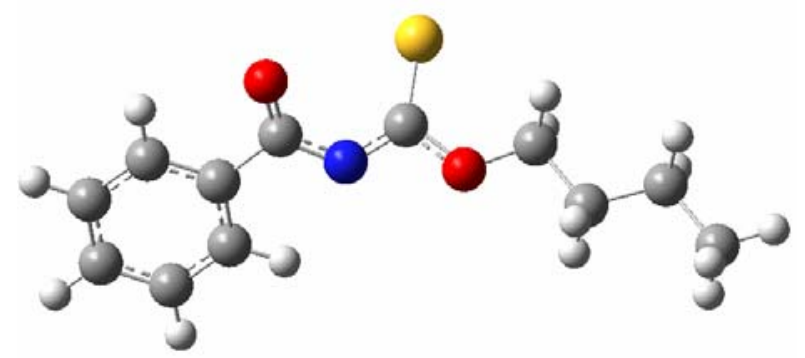

Figure 6. B3LYP/6-311G(d,p) optimized geometry for lowest energy conformer of butyl- $N$ benzoylthiocarbamate anion.

The yields of the $S$-alkylated product obtained form the isopropyl $N$-(2-furoyl)thiocarbamate showing a $E, Z^{\prime}$ conformation (see Figure 1) and those obtained from the methylation of butyl $N$ benzoylthiocarbamate being a Z,Z' conformation (see Figure 4), are quite similar $\sim 80 \%$ (see Table 1). This means that both geometries provide a greater access to the region of the sulphur atom compared to the $\mathrm{O}$ and $\mathrm{N}$ atoms in the polydentate system and this brings about a qualitative explanation for the higher percentage of the $S$-alkylated product in comparison to $\mathrm{N}$ and $O$-alkylation.

We have also calculated the net charges and the contribution of the three nucleophilic centers present in the anion to the HOMO of the molecule. The values are summarized in Table 4. These parameters are very useful that allow, in first approach the reactivity of the three different reaction sites.

Table 4. Calculated net charges on $\mathrm{S}, \mathrm{O}$ and $\mathrm{N}$ and orbital coefficient contribution of the $\mathrm{S}, \mathrm{N}$ and $\mathrm{O}$ atoms to the HOMO in the anion of butyl- $N$ benzoylthiocarbamate.

\begin{tabular}{cccccc}
\hline & Net charges & \multicolumn{3}{c}{ Orbitalic coefficient } \\
\hline $\mathrm{S}$ & $\mathrm{N}$ & $\mathrm{O}$ & $\mathrm{S}$ & $\mathrm{N}$ & $\mathrm{O}$ \\
-0.262 & -0.305 & -0.262 & 0.63 & 0.11 & 0.01 \\
\hline
\end{tabular}


The atomic charges predicts by the theoretical method, indicate that the sulphur atom to be the less negative in comparison with the $\mathrm{O}$ and $\mathrm{N}$ atoms. The orbital coefficient calculations of the different centres show that the contribution to the formation of the HOMO is nearly exclusively from the sulphur atom. The highest occupied molecular orbital is mainly localised on this centre, while the other two atoms $(\mathrm{O}$ and $\mathrm{N})$ have a negligible contribution to the HOMO (see Figure 7). These findings reveals the preferential alkylation on the sulphur atom and indicate the high influence that the orbital component has on those reactions in which the anion exhibits a remarkable nucleophilic character.

Both data series, steric factors and the nucleophilic character of $\mathrm{S}$ atom in this polydentate system, reveals the preferented alkylation on the sulfur atom.

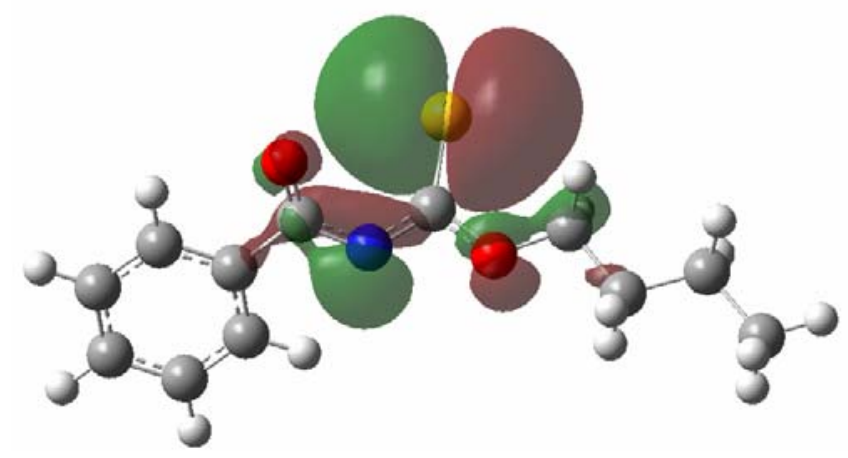

Figure 7. HOMO molecular orbital of butyl $\mathrm{N}$-benzoylthiocarbatamte anion.

\section{Conclusions}

In summary, the methylation reactions of the polydentate system $N$-acylthiocarbamate $\mathbf{1}$ have been studied. Although the synthesis of a mixture of three isomers, derived from the $\mathrm{N}-\mathrm{O}$ - and $S$-alkylation, is possible, only the $S$-alkylated product was isolated. The X-ray study of $N$-furoyland $N$-benzoylthiocarbamate indicates that both $E, Z$ ' and $Z, Z$ ' conformations where the sulphur atom is readily available for the electrophilic attack in comparison with the more sterically hindered nitrogen and oxygen atoms, account for the highly selective $S$-alkylation. Theoretical calculations also explain the behaviour of the methylation of alkyl $\mathrm{N}$-acyltiocarbamates. The novel carbonimidothioates 3a-g synthesized were fully characterized by spectroscopic methods.

\section{Experimental Section}

General. Melting points were determined in a capillary tube in an Electrothermal C14500 apparatus and are uncorrected. ${ }^{1} \mathrm{H}$ and ${ }^{13} \mathrm{C}$ NMR spectra were recorded in Bruker Advance-250 in $\mathrm{CDCl}_{3}$ at $250 \mathrm{MHz}$ and $62.0 \mathrm{MHz}$, respectively. Chemical shifts are given in ppm relative to 
tetramethylsilane (TMS), which was used as an internal standard. The values of coupling constants $J$ are given in Hz. The IR spectra $\left(v \mathrm{max} / \mathrm{cm}^{-1}\right)$ were recorded by using $\mathrm{KBr}$ disc. Microanalyses were performed in the Servicio de Microanálisis of Universidad Complutense de Madrid. The reactions were monitored by TLC performed on silica-gel plates $\left(\right.$ Merck $\left.60 \mathrm{~F}_{250}\right)$ and using ethyl acetate:hexane (5:1.5) as the eluent. HPLC was performed using a Waters Alliance 2695 (Waters, MA, USA) chromatography system with a PDA 995 detector, a reverse-phase Symmetry $\mathrm{C} 18$ column, and $\mathrm{H}_{2} \mathrm{O}$ with $0.045 \%$ TFA and $\mathrm{MeCN}$ with $0.036 \%$ TFA as mobile phases. The ab initio calculations were carried out with the DFT method using the B3LYP functional with the basis set $6-311 \mathrm{G}(\mathrm{d}, \mathrm{p})$ for the neutral molecule and $6-311 \mathrm{G}+(\mathrm{d}, \mathrm{p})$ for the anion. The calculation was performed using the Gaussian 03 program. $^{24}$

Synthesis of butyl $\boldsymbol{N}$-benzoylthiocarbamate. ${ }^{21}$ To a solution of benzoyl chloride $(2.84 \mathrm{~g}, 0.02$ $\mathrm{mol})$ in dry acetone, ammonium thiocyanate $(1.52 \mathrm{~g}, 0.02 \mathrm{~mol})$ in acetone was added slowly. The mixture was stirred until a precipitate of ammonium chloride appeared. The precipitate indicated the formation of the benzoylisothiocyanate. In that moment, $1.48 \mathrm{~g}(0.02 \mathrm{~mol})$ of butanol dissolved in acetone was added to the reaction mixture. The mixture was stirred for $5 \mathrm{~h}$. The progress of the reaction was monitored by TLC (using toluene/methanol (9/1) as eluent). When the reaction was completed the product was poured into $100 \mathrm{~mL}$ of cold water. The solid was filtered out. Purification of the compound was performed by recrystallization using acetone $-\mathrm{H}_{2} \mathrm{O}$ as solvent. $76 \%$ Yield. mp 60-62 ${ }^{\circ} \mathrm{C}$. IR (KBr) $v$ max, $\mathrm{cm}^{-1} 3251(\mathrm{NH}), 1694(\mathrm{C}=\mathrm{O}), 1600$ $(\mathrm{C}=\mathrm{C}), 1531(\delta \mathrm{NH}), 1300(\mathrm{~N}-\mathrm{C}=\mathrm{S}) ;{ }^{1} \mathrm{H} \mathrm{NMR}\left(\mathrm{CDCl}_{3}\right), \delta 1.00\left(\mathrm{t}, J=6.11 \mathrm{~Hz}, 3 \mathrm{H}, \mathrm{CH}_{3}\right), 1.45$ $\left(\mathrm{m}, 2 \mathrm{H}, \mathrm{CH}_{2}\right), 1.83\left(\mathrm{~m}, 2 \mathrm{H}, \mathrm{CH}_{2}\right), 4.60\left(\mathrm{t}, J=6.1 \mathrm{~Hz}, 2 \mathrm{H}, \mathrm{OCH}_{2}\right), 7.70(\mathrm{~m}, 5 \mathrm{H}, \mathrm{Ph}), 9.33(\mathrm{~s}, 1 \mathrm{H}$, $\mathrm{NH}), \mathrm{NMR}-{ }^{13} \mathrm{C}\left(\mathrm{CDCl}_{3}\right) \delta 13.6\left(\mathrm{CH}_{3}\right) .19 .0\left(\mathrm{CH}_{2}\right), 30.1\left(\mathrm{CH}_{2}\right), 73.4\left(\mathrm{OCH}_{2}\right), 127.7(\mathrm{C} 1, \mathrm{C} 5)$, 128.8 (C3, C6), 132.9 (C4), 133.0 (C6), 162.7 (CO), 189.7 (CS). Anal. Calcd for $\mathrm{C}_{12} \mathrm{H}_{15} \mathrm{NO}_{2} \mathrm{~S}$ : C, 60.73; H, 6.37; N, 5.90. Found: C, 60.79; H, 6.31; N, $5.85 \%$.

\section{$\mathrm{X}$-ray structure analysis}

Crystal data collection and processing. Crystals of butyl $\mathrm{N}$-benzoylthiocarbate were ground after slow evaporation from acetone solution. Single crystals suitable for X ray diffraction were obtained in a Nonius four circle diffractometer. The structures were solved by direct methods and the missing atoms were found on a difference-Fourier synthesis. The coordinates of the $\mathrm{H}$ atoms attached to nitrogen were refined isotropically. The programs SHELXL-97 ${ }^{25}$ and Ortep $\mathrm{III}^{26}$ were used for the crystal structure refinement and the graphics processing, respectively. Scattering factors were taken from International Tables for X-ray Crystallography. ${ }^{27}$ All the calculations were done with the WINGX PC program package. ${ }^{28}$ The crystallographic and experimental data for these compounds are summarised in Table 5. Detailed crystallographic data have been deposited at the Cambridge Crystallographic Data Centre (CCDC 736719) and are available on request. 
Table 5. Crystal data and the figures of merit obtained during the crystal structure refinement for Butyl N-benzoylthiocarbamate

\begin{tabular}{|c|c|}
\hline Crystal data & Compound \\
\hline Empirical formula & $\mathrm{C}_{12} \mathrm{H}_{15} \mathrm{NO}_{2} \mathrm{~S}$ \\
\hline Formula weight & 237.3 \\
\hline Crystal System & Monoclinic \\
\hline Space group & $\mathrm{P} 2{ }_{1} / \mathrm{n}$ \\
\hline \multicolumn{2}{|l|}{ Unit cell dimensions } \\
\hline $\mathrm{a}(\AA)$ & $9.155(8)$ \\
\hline $\mathrm{b}(\AA)$ & $17.074(14)$ \\
\hline$c(\AA)$ & $9.425(7)$ \\
\hline$\alpha\left(^{\circ}\right)$ & 90.00 \\
\hline$\beta\left(\left(^{\circ}\right)\right.$ & $118.81(1)$ \\
\hline$\gamma\left(\left(^{\circ}\right)\right.$ & 90.00 \\
\hline Volume $\left(\AA^{3}\right)$ & $1290.9(1)$ \\
\hline $\mathrm{Z}, \operatorname{Density}_{\text {(cal.) }}\left(\mathrm{mg} / \mathrm{m}^{3}\right)$ & $4,1.221$ \\
\hline Absorption coefficient $\left(\mathrm{mm}^{-1}\right)$ & 0.237 \\
\hline Radiation/wavelength $(\AA)$ & Mo Ka/0.7107 \\
\hline Reflections collected & 10607 \\
\hline Independent reflections & 2391 \\
\hline Observed reflections & $1649(\mathrm{I}>2 \sigma(\mathrm{I})$ \\
\hline Goodness of fit & 1.006 \\
\hline Final $\mathrm{R}$ indices & R- 0.082 wR- 0.162 \\
\hline Largest diff. peak/hole (e $\left.\AA^{-3}\right)$ & 0.302 and -0.119 \\
\hline
\end{tabular}

\section{Methylation of alkyl $\mathrm{N}$-acylthiocarbamates 1}

A mixture of the appropriate alkyl $\mathrm{N}$-acylthiocarbamate $\mathbf{1}(8 \mathrm{mmol})$, dry potassium carbonate $(8$ $\mathrm{mmol})$ in dry DMF $(20 \mathrm{~mL})$, was stirred for $15 \mathrm{~min}$. Then, a solution of dimethyl sulfate in dry DMF $(10 \mathrm{~mL})$ was added and the mixture reaction was heated at reflux for $4 \mathrm{~h}$. After this time, the reaction was poured into ice-water. Further purification of compounds 2 was accomplished by recrystallization from acetone.

Note: Dimethyl sulfate is a very toxic reagent: it must be handled as a possible carcinogen, using safety glasses, rubber gloves and the use of a good ventiled fume hood.

$\boldsymbol{O}, \boldsymbol{S}$-Dimethyl $\boldsymbol{N}$-(2-furoyl)carbonimidothioate (3a). $82 \%$ yield (from acetone), mp 122$124^{\circ} \mathrm{C}$; IR (KBr) $v_{\max } / \mathrm{cm}^{-1} 1630(\mathrm{C}=\mathrm{O}), 1522(\mathrm{C}=\mathrm{N}), 1463(\mathrm{C}=\mathrm{C}) ;{ }^{1} \mathrm{H} \mathrm{NMR}\left(\mathrm{CDCl}_{3}\right) \delta 2.34(\mathrm{~s}$, $\left.3 \mathrm{H}, \mathrm{SCH}_{3}\right), 4.19\left(\mathrm{~s}, 3 \mathrm{H}, \mathrm{OCH}_{3}\right), 6.49\left(\mathrm{dd}, J_{4,3}=3.4 \mathrm{~Hz}, J_{4,5}=1.7 \mathrm{~Hz}, 1 \mathrm{H}, \mathrm{H} 4\right), 7.10\left(\mathrm{~d}, J_{3,4}=3.4\right.$ $\mathrm{Hz}, 1 \mathrm{H}, \mathrm{H} 3), 7.58\left(\mathrm{~d}, J_{5,4}=1.7 \mathrm{~Hz}, 1 \mathrm{H}, \mathrm{H} 5\right) ;{ }^{13} \mathrm{C} \mathrm{NMR}\left(\mathrm{CDCl}_{3}\right) \delta 13.9\left(\mathrm{SCH}_{3}\right), 58.9\left(\mathrm{OCH}_{3}\right)$, $111.6(\mathrm{C} 4), 117.8(\mathrm{C} 3), 146.2(\mathrm{C} 5) 150.4(\mathrm{C} 2), 167.3(\mathrm{C}=\mathrm{O}), 172.9(\mathrm{C}=\mathrm{N})$. Anal. Calcd for $\mathrm{C}_{8} \mathrm{H}_{9} \mathrm{NO}_{3} \mathrm{~S}: \mathrm{C}, 48.23 ; \mathrm{H}, 4.55 ; \mathrm{N}, 7.03$. Found: $\mathrm{C}, 48.32 ; \mathrm{H}, 4.60 ; \mathrm{N}, 7.08 \%$. 
$\boldsymbol{O}$-Ethyl $\boldsymbol{S}$-methyl $\boldsymbol{N}$-(2-furoyl)carbonimidothioate (3b). $81 \%$ yield (from acetone), mp 118 $119^{\circ} \mathrm{C}$; IR $(\mathrm{KBr}) v_{\max } / \mathrm{cm}^{-1} 1631(\mathrm{C}=\mathrm{O}), 1522(\mathrm{C}=\mathrm{N}) 1464(\mathrm{C}=\mathrm{C}) ;{ }^{1} \mathrm{H}$ NMR $\left(\mathrm{CDCl}_{3}\right) \delta 1.42(\mathrm{t}, J$ $\left.=6.1 \mathrm{~Hz}, 3 \mathrm{H}, \mathrm{CH}_{3}\right), 2.36\left(\mathrm{~s}, 3 \mathrm{H}, \mathrm{SCH}_{3}\right), 4.51\left(\mathrm{q}, 2 \mathrm{H}, J=6.1 \mathrm{~Hz}, \mathrm{OCH}_{2}\right), 6.48\left(\mathrm{dd}, J_{4,3}=3.4 \mathrm{~Hz}\right.$, $\left.J_{4,5}=1.7 \mathrm{~Hz}, 1 \mathrm{H}, \mathrm{H} 4\right), 7.11\left(\mathrm{~d}, J_{3,4}=3.4 \mathrm{~Hz}, 1 \mathrm{H}, \mathrm{H} 3\right), 7.58\left(\mathrm{~d}, J_{5,4}=1.7 \mathrm{~Hz}, 1 \mathrm{H}, \mathrm{H} 5\right) ;{ }^{13} \mathrm{C} \mathrm{NMR}$ $\left(\mathrm{CDCl}_{3}\right) \delta 13.9\left(\mathrm{SCH}_{3}\right), 14.0\left(\mathrm{CH}_{3}\right), 66.9\left(\mathrm{OCH}_{2}\right), 111.9(\mathrm{C} 4), 118.1(\mathrm{C} 3), 146.6(\mathrm{C} 5), 150.3$ (C2), $166.5(\mathrm{C}=\mathrm{O}), 173.0(\mathrm{C}=\mathrm{N})$. Anal. Calcd for $\mathrm{C}_{9} \mathrm{H}_{11} \mathrm{NO}_{3} \mathrm{~S}$ : C, 50.69; H, 5.20; N, 6.57. Found: C, 50.63; H, 5.25; N, $6.60 \%$.

$S$-Methyl $\boldsymbol{O}$-isopropyl $\mathrm{N}$-(2-furoyl)carbonimidothioate (3c). $79 \%$ yield (from acetone), $\mathrm{mp}$ 120-121 ${ }^{\circ} \mathrm{C}$; IR $(\mathrm{KBr}) v_{\max } / \mathrm{cm}^{-1} 1635(\mathrm{C}=\mathrm{O}), 1520(\mathrm{C}=\mathrm{N}), 1464(\mathrm{C}=\mathrm{C}) ;{ }^{1} \mathrm{H} \mathrm{NMR}\left(\mathrm{CDCl}_{3}\right) \delta 1.43$ $\left(\mathrm{d}, J=6.5 \mathrm{~Hz}, 6 \mathrm{H}, \mathrm{CH}_{3}\right) ; 2.35\left(\mathrm{~s}, 3 \mathrm{H}, \mathrm{SCH}_{3}\right), 5.40(\mathrm{~h}, J=6.5 \mathrm{~Hz}, 1 \mathrm{H}, \mathrm{CH}), 6.70\left(\mathrm{dd}, J_{4,3}=3.4\right.$ $\left.\mathrm{Hz}, J_{4,5}=1.6 \mathrm{~Hz}, 1 \mathrm{H}, \mathrm{H} 4\right), 7.20\left(\mathrm{~d}, J_{3,4}=3.4 \mathrm{~Hz}, 1 \mathrm{H}, \mathrm{H} 3\right), 7.55\left(\mathrm{~d}, J_{5,4}=1.6 \mathrm{~Hz}, 1 \mathrm{H}, \mathrm{H} 5\right) ;{ }^{13} \mathrm{C}$ NMR $\left(\mathrm{CDCl}_{3}\right) \delta 13.8\left(\mathrm{SCH}_{3}\right), 23.2\left(\mathrm{CH}_{3}\right), 70.0(\mathrm{OCH}), 111.8(\mathrm{C} 4), 118.0(\mathrm{C} 3), 146.4(\mathrm{C} 5)$, $150.6(\mathrm{C} 2), 166.3(\mathrm{C}=\mathrm{O}), 173.8(\mathrm{C}=\mathrm{N})$. Anal. Calcd for $\mathrm{C}_{10} \mathrm{H}_{13} \mathrm{NO}_{3} \mathrm{~S}: \mathrm{C}, 52.85 ; \mathrm{H}, 5.77 ; \mathrm{N}, 6.16$. Found: C, 52.80; H, $5.82 \mathrm{~N}, 6.09 \%$.

$\boldsymbol{O}, S$-Dimethyl $N$-benzoyl carbonimidothioate (3d). $81 \%$ yield (from acetone), mp $87-88^{\circ} \mathrm{C}$; IR $(\mathrm{KBr}) v_{\max } / \mathrm{cm}^{-1} 1640(\mathrm{C}=\mathrm{O}), 1520(\mathrm{C}=\mathrm{C}), 1468(\mathrm{C}=\mathrm{N}) ;{ }^{1} \mathrm{H}$ NMR $\left(\mathrm{CDCl}_{3}\right) \delta 2.36(\mathrm{~s}, 3 \mathrm{H}$, $\left.\mathrm{SCH}_{3}\right), 4.08\left(\mathrm{~s}, 3 \mathrm{H}, \mathrm{OCH}_{3}\right), 8.25-7.35(\mathrm{~m}, 5 \mathrm{H}, \mathrm{Ph}),{ }^{13} \mathrm{C} \mathrm{NMR}\left(\mathrm{CDCl}_{3}\right) \delta 13.9\left(\mathrm{SCH}_{3}\right), 57.5$ $\left(\mathrm{OCH}_{3}\right), 128.3(\mathrm{C} 7, \mathrm{C} 9), 129.8(\mathrm{C} 6, \mathrm{C} 10), 132.8(\mathrm{C} 5), 135.2(\mathrm{C} 8), 162.0(\mathrm{C}=\mathrm{O}), 175.8(\mathrm{C}=\mathrm{N})$. Anal. Calcd for $\mathrm{C}_{10} \mathrm{H}_{11} \mathrm{NO}_{2} \mathrm{~S}$ : C, 57.39; H, 5.30; N, 6.69. Found: C, 57.43; H, $5.36 \mathrm{~N}, 6.62 \%$.

$\boldsymbol{S}$-Methyl $\boldsymbol{O}$-butyl $\boldsymbol{N}$-benzoyl carbonimidothioate (3e). $80 \%$. yield (from acetone), mp 70 $72^{\circ} \mathrm{C}$;. IR (KBr) $v_{\max } \mathrm{cm}^{-1}: 1623(\mathrm{C}=\mathrm{O}), 1483(\mathrm{C}=\mathrm{N}), 1534(\mathrm{C}=\mathrm{C}), \mathrm{NMR}-{ }^{1} \mathrm{H}\left(\mathrm{CDCl}_{3}\right) \delta 0.96(\mathrm{t}, J$ $\left.=6.1 \mathrm{~Hz}, 3 \mathrm{H}, \mathrm{CH}_{3}\right), 1.33\left(\mathrm{~m}, 2 \mathrm{H}, \mathrm{CH}_{2}\right), 1.48\left(\mathrm{~m}, 2 \mathrm{H}, \mathrm{CH}_{2}\right), 3.53\left(\mathrm{t}, J=6.1 \mathrm{~Hz}, 2 \mathrm{H}, \mathrm{OCH}_{2}\right), 2.00$ (s, 3H, $\left.\mathrm{SCH}_{3}\right), 7.69(\mathrm{~m}, 5 \mathrm{H}, \mathrm{Ph}) ;{ }^{13} \mathrm{C}\left(\mathrm{CDCl}_{3}\right) \delta 11.5\left(\mathrm{SCH}_{3}\right), 14.1\left(\mathrm{CH}_{3}\right), 18.8\left(\mathrm{CH}_{2}\right), 31.7$ $\left(\mathrm{CH}_{2}\right), 61.0\left(\mathrm{OCH}_{2}\right), 129.3(\mathrm{C} 3, \mathrm{C} 5), 129.9(\mathrm{C} 2, \mathrm{C} 6), 134.6(\mathrm{C} 4), 135.4(\mathrm{C} 1), 163.0(\mathrm{C}=\mathrm{O})$, 174.6 $(\mathrm{C}=\mathrm{N})$. Anal. Calcd for $\mathrm{C}_{13} \mathrm{H}_{17} \mathrm{NO}_{2} \mathrm{~S}: \mathrm{C}, 62.12 ; \mathrm{H}, 6.82, \mathrm{~N}, 5.57$. Found: $\mathrm{C}, 62.19 ; \mathrm{H}, 6.90$; $\mathrm{N}, 5.61 \%$.

$S$-Methyl $\boldsymbol{O}$-isopropyl $\mathrm{N}$-(p-nitrobenzoyl)carbonimidothioate (3f). $77 \%$ yield (from acetone), mp 150-152 ${ }^{\circ} \mathrm{C}$; IR $(\mathrm{KBr}) v_{\max } / \mathrm{cm}^{-1} 1645(\mathrm{C}=\mathrm{O}), 1601(\mathrm{C}=\mathrm{C}), 1520(\mathrm{C}=\mathrm{N}), 1550\left(v^{\mathrm{a}} \mathrm{NO}_{2}\right), 1350$ $\left(v^{\mathrm{s}} \mathrm{NO}_{2}\right) ;{ }^{1} \mathrm{H}$ NMR $\left(\mathrm{CDCl}_{3}\right) \delta 1.41\left(\mathrm{~d}, J=6.1 \mathrm{~Hz}, 6 \mathrm{H}, \mathrm{CH}_{3}\right), 2.36\left(\mathrm{~s}, 3 \mathrm{H}, \mathrm{SCH}_{3}\right), 5.65(\mathrm{~h}, J=6.1$ $\mathrm{Hz}, 1 \mathrm{H}, \mathrm{CH}), 8.04$ (d, $J=8.2 \mathrm{~Hz}, 2 \mathrm{H}, \mathrm{H} 2, \mathrm{H} 6), 8.30$ (d, $J=8.2 \mathrm{~Hz}, 2 \mathrm{H}, \mathrm{H} 3, \mathrm{H} 5) ;{ }^{13} \mathrm{C}$ NMR $\left(\mathrm{CDCl}_{3}\right) \delta 13.9\left(\mathrm{SCH}_{3}\right), 24.2\left(2 \times \mathrm{CH}_{3}\right), 71.0(\mathrm{OCH}), 123.8(\mathrm{C} 3, \mathrm{C} 5), 128.9(\mathrm{C} 2, \mathrm{C} 6), 137.8$ (C1), $149.6(\mathrm{C} 4), 165.2(\mathrm{C}=\mathrm{O}), 172.2(\mathrm{C}=\mathrm{N})$. Anal. Calcd for $\mathrm{C}_{12} \mathrm{H}_{14} \mathrm{~N}_{2} \mathrm{O}_{4} \mathrm{~S}: \mathrm{C}, 51.05 ; \mathrm{H}, 5.00$; N, 9.92. Found: C, $51.28 ; \mathrm{H}, 5.22 \mathrm{~N}, 9.70 \%$.

$S$-Methyl $O$-isopropyl $\mathrm{N}$-(p-fluorobenzoyl)carbonimidothioate $\mathbf{( 3 g ) .} 76 \%$ yield (from acetone), mp 162-164 ${ }^{\circ} \mathrm{C}$; IR ( KBr) $v_{\max } / \mathrm{cm}^{-1} 1647(\mathrm{C}=\mathrm{O}), 1604(\mathrm{C}=\mathrm{C}), 1516(\mathrm{C}=\mathrm{N}) ;{ }^{1} \mathrm{H}$ NMR $\left(\mathrm{CDCl}_{3}\right) \delta 1.42\left(\mathrm{~d}, J=6.3 \mathrm{~Hz}, 6 \mathrm{H}, \mathrm{CH}_{3}\right), 2.35\left(\mathrm{~s}, 3 \mathrm{H}, \mathrm{SCH}_{3}\right), 5.61(\mathrm{~h}, J=6.3 \mathrm{~Hz}, 1 \mathrm{H}, \mathrm{CH}), 7.16$ (t, $J=8.5 \mathrm{~Hz}, 2 \mathrm{H}, \mathrm{H} 2, \mathrm{H} 6), 7.87(2 \mathrm{H}, \mathrm{q}, J=5.1 \mathrm{~Hz}, \mathrm{H} 3, \mathrm{H} 5) ;{ }^{13} \mathrm{C} \mathrm{NMR}\left(\mathrm{CDCl}_{3}\right) \delta 12.1\left(\mathrm{SCH}_{3}\right)$; $24.3\left(2 \times \mathrm{CH}_{3}\right), 53.1(\mathrm{OCH}) ; 115.7,115.3(\mathrm{C} 3, \mathrm{C} 5), 131.1,131.3(\mathrm{C} 2, \mathrm{C} 6), 162.1(\mathrm{C} 4), 128.5$ (C1), $165.3(\mathrm{C}=\mathrm{O}), 170.6(\mathrm{C}=\mathrm{N})$., Anal. Calcd for $\mathrm{C}_{12} \mathrm{H}_{14} \mathrm{FNO}_{2} \mathrm{~S}: \mathrm{C}, 56.45 ; \mathrm{H}, 5.53 ; \mathrm{N}, 5.49$. Found: C, 56.50; H, $5.60 \mathrm{~N}, 5.54 \%$. 


\section{Acknowledgements}

Part of this work was supported by the MICINN of Spain (project CT2008-00795/BQU and Consolider-Ingenio 2010C-07-25200).

\section{References}

1. (a) Le Noble, W. J. Synthesis 1970, 1-6. (b) Koos, M. Monatsh. Chem. 1994, 125, 10111016. (c) Nagasawa, H.; Mitsunobu, O. Bull. Chem. Soc. Jpn 1981, 54, 2223.

2. (a) Braband, H.; Abram, U. J. Organometallic Chem. 2004, 689, 2066. (b) Campo, R.; Criado, J.; Gheorghe, R.; González, F.; Hermosa, M. R.; Sanz, F.; Manzano, J. L.; Monte, E.; Rodríguez-Fernández, E. J. Inorg. Biochem. 2004, 98, 1307. (c) Tadjarodi, A.; Adhami, F.; Hanifehpour, Y.; Yazdi, M.; Moghaddamfard, Z.; Kickelbic, G. Polyhedron, 2007, 26, 4609. (d) Safin, D.; Sokolov, F. D.; Szyrwiel, Ł.; Baranov, S. V.; Babashkina, M. G.; Gimadiev, T.; Kozlowski, H.; Butlerov, A.M. Polyhedron 2008, 27, 1995.

3. (a) Walter, W.; Bode, K.D. Angew. Chem., Int. Ed. Engl. 1967, 6, 281. (b) Alexander, B.H.; Gertler, S.I.; Oda, T.A.; Brown, R.T.; Ihndris, R.W.; Beroza, M. J. Org. Chem. 1960, 25 , 626.

4. (a) Rodis, N. P.; Digenis, G. A. J. Enzyme Inhibition 2001, 16, 95. (b) Li-Pan, Z. S.; Joshi, H. V.; Digenis, G. A. J. Enzyme Inhibition 1999, 15, 63.

5. Spallarossa, A.; Cesarini, S.; Schenone, S.; Ranise, A. Arch. Pharm. 2009, 342, 344.

6. Sondhi, S. M.; Verma, R. P.; Singhal, N.; Shukla, R.; Raghubir, R.; Dubey, M. P. Indian Drugs 1999, 36, 50.

7. (a) Bajaj, S.; Sambi, S. S.; Madan, A. K. Bioorg. Med. Chem. 2005, 13, 3263. (b) Spallarossa, A.; Cesarini, S.; Ranise, A.; Schenone, S.; Bruno, O.; Borassi, A.; La Colla, P.; Pezzullo, M.; Sanna, G.; Collu, G.; Secci, B.; Loddo, R. Eur. J. Med. Chem. 2009, 44, 2190. (c) Mugnoli, A.; Borassi, A.; Spallarossa, A.; Cesarini, S. Acta Cryst., 2006, C62, o315.

8. Oba, M.; Nishiyama, K. Synthesis 1994, 624.

9. Schroeder, U.; Beyer, L.; Dietze, R.; Richter, S.; Schmidt, S.; Hoyer, E. J. Prakt. Chem. 1995, 337, 184.

10. Quas, L.; Schröder, U.; Schröder, B.; Dietze, F.; Beyer, L. Solvent Extr. Ion Exch. 2000, 18, 1167.

11. Ribeiro da Silva, M. A. V.; Santos, L. N. B.; Schroder, B.; Dietze, F.; Beyer, L. J. Chem. Thermodyn. 2004, 36, 627.

12. Quas, L.; T. Ristau, U. Schröder, F. Dietze, L. Beyer, Z. Anorg, Allg. Chem. 2001, 627, 1909.

13. Morales, A. D.; De Armas, H. N.; Blaton, N. M.; Peeters, O. M.; De Ranter, C. J.; Márquez, H.; Hernández, R. P. Acta Cryst. 2000, C56, 1042. 
14. Montiel-Ortega, L. A.; Rojas-Lima, S.; Otazo-Sanchez, E.; Villagomez-Ibarra, R. J. Chem. Crystallogr. 2004, 34, 89.

15. Blewett, G.; Esterhuysen, C.; Bredenkamp, M. W.; Koch, K. R. Acta Cryst. 2004, C60, 0862.

16. Blewett, G.; Bredenkamp, M. W.; Koch, K. R. Acta Cryst. 2005, C61, o469.

17. Ottenbrite, R. M. J. Chem. Soc., Perkin Trans. 1 1972, 88.

18. Ares, J. J.; Urchek, T. G.; Palmer, C. W.; Miller, D. D. Magn. Reson. Chem. 1986, $24,460$.

19. Quante, J. M.; Hoke, R. A.; Mize, P. D.; Woodard, D. L.; Willner O. L. USA Patent, 5516 902, 1996; Chem. Abstr. 1996, 125, 50759z.

20. Plutín, A.; Márquez, H.; Ochoa, E.; Morales, M.; Sosa, M.; Moran, L.; Rodríguez, Y.; Suárez, M.; Martín, N.; Seoane, C. Tetrahedron 2000, 56, 1533.

21. Plutín, A.; Suárez, M.; Ochoa, E.; Machado, T.; Mocelo, R.; Concellón, J. M.; RodríguezSolla, H. Tetrahedron 2005, 61, 5812.

22. Insuasty, H.; Castro, E.; Sánchez, E.; Cobo, J.; Gildewell, C. Acta Cryst. 2010, C66, o141.

23. A similar C-N distance is observed for thiourea derivatives: Arslan, H.; Flörke, U.; Külcü, N. Transit. Met. Chem. 2003, 28, 816

24. Gaussian 03, Revision A.1, Frisch, M. J.; Trucks, G. W.; Schlegel, H. B.; Scuseria, G. E.; Robb, M. A.; Cheeseman, J. R.; Montgomery, Jr. J. A.; Vreven, T.; Kudin, K. N.; Burant, J. C.; Millam, J. M.; Iyengar, S. S.; Tomasi, J.; Barone, V.; Mennucci, B.; Cossi, M.; Scalmani, G.; Rega, N.; Petersson, G. A.; Nakatsuji, H.; Hada, M.; Ehara, M.; Toyota, K.; Fukuda, R.; Hasegawa, J.; Ishida, M.; Nakajima, T.; Honda, Y.; Kitao, O.; Nakai, H.; Klene, M.; Li, X.; Knox, J. E.; Hratchian, H. P.; Cross, J. B.; Adamo, C.; Jaramillo, J.; Gomperts, R.; Stratmann, R. E.; Yazyev, O.; Austin, A. J.; Cammi, R.; Pomelli, C.; Ochterski, J. W.; Ayala, P. Y.; Morokuma, K.; Voth, G. A.; Salvador, P.; Dannenberg, J. J.; Zakrzewski, V. G.; Dapprich, S.; Daniels, A. D.; Strain, M. C.; Farkas, O.; Malick, D. K.; Rabuck, A. D.; Raghavachari, J. B.; Foresman, J. V.; Ortiz, Q.; Cui, A. G.; Baboul, S.; Clifford, J.; Cioslowski, K.; Stefanov, B. B.; Liu, G.; Liashenko, A.; Piskorz, P.; Komaromi, I.; Martin, R. L.; Fox, D. J.; Keith, T.; Al-Laham, M. A.; Peng, C. Y.; Nanayakkara, A.; Challacombe, M.; Gill, P. M. W.; Johnson, B.; Chen, W.; Wong, M. W.; Gonzalez, C.; Pople, J. A. Gaussian, Inc., Pittsburgh PA, 2003.

25. Sheldrick, G.M. SHELX97. Programs for Crystal Structure Analysis (Release 97-2). University of Göttingen, Germany. 1997.

26. Farrugia, L. J. OrtepIII Program, J. Appl. Cryst., 1997, 30, 565.

27. International tables for X-ray Crystallography, Vol. C. Kluwer, Academic Publishers, Dordrecht, The Netherlands, 1995.

28. Farrugia, L. J. WINGX PC program package, J. Appl. Cryst. 1999, 32, 837. 